\title{
Beyond Humanitarian Relief: Social Networks and the Role of Shared Identity in Refugee Belonging and Support in Turkey
}

\author{
Michael Kaplan
}

\begin{abstract}
A considerable body of research explores the ways in which refugees exert agency and establish belonging in exile. This scholarship challenges popular tropes that reduce the varied experiences of displacement to generalized themes of crisis, uprootedness, and suffering. Through exploring refugee involvement in Islamic communities in Turkey, this paper considers the role played by informal social networks and actors in both helping Syrian refugees to secure their basic needs, as well as in fostering subjectivities of belonging. Drawing on secondary research as well as on participant observation and interviews conducted with Syrians living in Turkey, it argues that attention to social networks built upon shared modes of identification, such as being devoutly religious, can offer generative insight into processes of emplacement among refugees. These networks not only make visible some of the problematic aspects of humanitarianism associated with non-governmental organizations, but also present alternative models built upon mutual support and care. At the same time, while recognizing the benefits of informal social networks, this paper also considers the potential for new boundaries and exclusions to emerge where others recede.
\end{abstract}

\section{Introduction}

In December 2012, Hisham, then a 20-year-old Syrian, arrived at the Turkish border province of Hatay to receive medical treatment for wounds sustained while fighting alongside the Free Syrian Army (FSA). Unlike the many Syrians who sought support through a network of non-governmental organisations (NGOs) along the border, Hisham remembered that he had met several Turkish students studying theology in Damascus while he was pursuing his undergraduate degree. He contacted them and found that they were eager to support their "Muslim brother." They travelled to Hatay to assist him through his medical treatments, and then accompanied him several months later to Istanbul, where they offered him housing and employment at an Islamic school they managed. Seven years later, Hisham is still involved with the school. As he explained:

If it wasn't for them, my experience in Turkey would have been very different. The people who were helping me did so based on religious reasons, not any other reasons, such as a humanitarian reason, or because they had to. It was their own choice. They came to see me, I didn't go to them. They came from Istanbul to Hatay to help me, and they brought me back to Istanbul on their own account... They told me, "Don't worry, we are going to take you with us. We will take care of everything." They were like my second family.

Hisham's story offers an alternative focus to policy-oriented scholarship in refugee and migration studies that emphasises legal, economic, and political precarity as the primary

\footnotetext{
${ }^{1}$ Interview by the author with Hisham, a Syrian refugee in Istanbul, Turkey, via Skype, 15 March 2019.
} 
experience of refugees in Turkey and the Middle East more broadly. ${ }^{2}$ Indeed, while he complained of many of the same bureaucratic complications that continue to burden Syrians living in Turkey, he had developed a tight-knit social network and a sense of belonging in Istanbul.

As Tara Polzer notes, academic scholarship has a tendency to overlook the experiences of refugees who are well-integrated into their host countries. ${ }^{3}$ While this derives, in part, from an interest in those who are most vulnerable and a desire to call into account government policies that disadvantage refugees, it simultaneously operates to reproduce an image of the refugee as a passive victim out of place and in need of saving. ${ }^{4}$ In this paper, I would like to suggest that, in the context of the large-scale displacements from Syria, attention to alternative modes of identification, such as being religiously affiliated, can provide a helpful mode of analysis for scholars seeking to understand emplacement among refugees. This approach considers forms of identification that become important in context of displacement, looking beyond national identity as the sole, or primary, social identifier. Indeed, among the Syrians I met in Turkey, those who had proclivities toward Islamic action and education often felt secure and confident about their place in the country. They had connected with informal support networks that, while assisting with practical concerns, such as finding housing and employment, also offered spiritual support, companionship, and community.

Much of this paper draws on secondary scholarship in the social sciences, primarily anthropology, pertaining to displacement and humanitarianism, suggesting approaches to understanding belonging, identity, and social networks. These secondary sources are supplemented through accounts from my own ethnographic fieldwork in Turkey in Summer 2019, as well as several earlier and extended periods of reporting as a journalist. ${ }^{56}$ I spent three months in the Istanbul neighborhood of Fatih, where I attended weekly gatherings organized by an Islamic community. Although institutionally independent, this community developed out of the larger Nurcu movement - a vast revivalist movement with various splinter communities that all read the writings of the Turkish theologian Said Nursi (d. 1960) - with the intention of reading Nursi's work in English. The community attracted educated Turks, international Muslims living in Turkey as professionals or students, and economic and political refugees. My research, which included participant observation and interviews with around a dozen Syrians, extended beyond the formal community, and instead considered the personal relationships interlocutors had built with one another. In light of discourses I regularly heard which depicted Istanbul as bifurcated between Syrian and Turkish spheres, I was surprised to find that many Syrian men $^{7}-$ sometimes in groups and sometimes as individuals - attended Turkish religious

\footnotetext{
${ }^{2}$ To read about the many legal challenges Syrians face, see: Feyzi Baban, Suzan Ilcan, and Kim Rygiel, "Syrian Refugees in Turkey: Pathways to Precarity, Differential Inclusion, and Negotiated Citizenship Rights," Journal of Ethnic and Migration Studies, 2017, Vol. 43(1), p. 41-57.

${ }^{3}$ Tara Polzer, "Invisible Integration: How Bureaucratic, Academic and Social Categories Obscure Integrated Refugees,” Journal of Refugee Studies, Oxford, Oxford University Press, 2008, p. 477.

${ }^{4}$ Critiques of depictions of refugees as passive and out of place are common, but are often influenced by Liisa Malkki, "Refugees and Exile: From 'Refugee Studies' to the National Order of Things." Annual Review of Anthropology, 1995, Vol. 24(1), p. 495-523.

${ }^{5}$ Note that names have been changed throughout the paper in order to protect the privacy of all interlocutors.

${ }^{6}$ While my experience as a journalist helped me to better understand the lives of my interlocutors, and to build important connections, this paper is primarily rooted in my recent ethnographic fieldwork.

${ }^{7}$ Due to cultural norms, I primarily had access to male gatherings.
} 
events and had become involved in Turkish Islamic communities, even in spite of language barriers. In general, when asked about their support and connections, they indicated that they did not receive services from formal NGOs and instead depended upon informal community relationships. Donations were distributed, not through organised humanitarian bureaucracies intended to aid refugees, but instead on ad hoc, case-by-case basis intended to help "a brother" in a difficult situation. I thus treat these religious communities as social networks, which I define as the interpersonal relationships through which migrants secure basic needs and develop feelings of emplacement and belonging.

In the analysis that follows, I present a broad overview of the situation for refugees in Turkey and raise questions pertaining to shared identity and Islam. I then explore the salience of the category of "refugee" and suggest ways in which their experiences align with, and diverge from, commonly held assumptions about refugees and humanitarian support. Not wanting to idealise the notion of a shared identity, in the conclusion, I suggest new problematics, fractures, and boundaries that have emerged in the context of socio-religious networks built upon shared affiliation. The conflict in Syria and the subsequent refugee influx has come about at a particularly critical juncture in Turkish history, insofar as religiosity as a unifying identity (among those Turks who do, indeed, identify as religious) has become an increasingly important social identifier under the Justice and Development Party (AKP). ${ }^{9}$ In some ways, Syrians are both the beneficiaries of the AKP's commitment to a pan-Islamic vision, one that expresses particular concerns about fellow Muslims in need and, as such, they are also held up as its evidence.

\section{Turkey as a Case for Thinking Outside the NGO}

Turkey provides an illustrative study into the practices of agency and emplacement among refugee communities. According to the Center for American Progress, a vast majority of Syrian refugees in Turkey, some 96 percent, live outside of refugee camps, in either urban or semi-urban areas. With nearly four million refugees living in Turkey, Syrian restaurants, cafes, and small businesses have been established throughout major cities. A majority of Syrians remain in the country's southern provinces, close to the Syrian border, but about one million Syrians are living in Istanbul, the economic capital. ${ }^{11}$ As Turkish authorities attempt to phase out the refugee camps, ${ }^{12}$ they are also implementing policies intended to integrate Syrian children

\footnotetext{
${ }^{8}$ Note that I borrow the first part of this definition, relating to basic needs, from Brigitte Suter, but add to the definition a sense of belonging, in line with how my interlocutors understood the role of these Islamic communities. Brigitte Suter, "Social Networks in Transit: Experiences of Nigerian Migrants in Istanbul," Journal of Immigrant \& Refugee Studies, 2012, Vol. 10 (2), p. 209.

${ }^{9}$ Ihsan Yilmaz, "Islamic Populism and Creating Desirable Citizens in Erdogan's New Turkey," Mediterranean Quarterly, 2018, Vol. 29(4), p. 52-76.

${ }^{10}$ The Islamist-leaning AKP, led by President Recep Tayyip Erdogan, encourages family values and has overturned many of Turkey's formerly secular laws. Under the AKP government, many Islamic organizations and communities have enjoyed widening influence throughout the country.

${ }^{11}$ This number is according to the Istanbul mayor, although only 500,000 Syrians are officially registered in the city, according to figures from the Interior Ministry. See: Sarah Dadouch and Khalil Ashawi, "Istanbul gives Syrians one month to return to provinces in which they are registered," website, Reuters, 22 July 2019, available at:

https://www.reuters.com/article/us-turkey-syrians/istanbul-gives-syrians-one-month-to-return-to-provinces-in-which -they-are-registered-idUSKCN1UH1Y6 [last accessed 20 August 2019].

${ }^{12}$ According to Alan Makoyvky, decisions to close the camps have been influenced, in part, by the economic success of Syrians residing outside of the camps; UN officials have also cited the importance of ensuring refugees are integrated into their "host" communities and live self-reliantly. Many refugees have themselves chosen to settle
} 
into Turkish schools and Syrian workers into the economic system. As various studies have shown, few refugees have plans to return home anytime in the foreseeable future. ${ }^{13}$ While some 75,000 Syrians have become naturalised Turkish citizens, a vast majority remain in limbo under temporary protection status. ${ }^{14}$ The situation of refugees in the country thus represents that of a refugee population and humanitarian situation that is indefinite and in process of growing long-term and multi-generational. ${ }^{15}$

To meet the needs of a diverse, and often economically desperate population, a vast network of NGOs exists in Turkey today. As of 2017, a Turkish official stated that 48 foreign NGOs had received permission to operate in the country, although some (including International Medical Corps and Mercy Corps) were shuttered for their alleged cooperation in providing Syrian Kurds with humanitarian relief. ${ }^{16}$ Many NGOs and international associations, including United Nations High Commissioner for Refugees (UNHCR), the United Nation's refugee agency, remain active in providing educational services and other programming and services to Syrians. However, a vast majority of humanitarian endeavours are led by Turkish NGOs, often working in partnership with international organisations. My interlocutors were most familiar with the work of the Foundation for Human Rights and Freedoms and Humanitarian Relief (IHH), a Turkish Islamic charity that operates globally. Their headquarters is located in the neighbourhood of Fatih in Istanbul, where my interlocutors primarily lived.

Because this paper focuses precisely on those refugees who "don't need help" - at least not from international NGOs - and who are "not immediately distinguishable from the general population," quantitative data is difficult to come by. ${ }^{17}$ That noted, I do not intend to argue whether or not these experiences of participation in religious life, or in other forms of social networks, are reflective of a substantial percentage of Syrians living in Turkey. However, areas where Syrian commercial activities and social lives thrive, such as in the Fatih neighbourhood of Istanbul, suggest that many Syrians have built lives for themselves and experience emplacement and belonging in Turkey - which, of course, is not to suggest that they are content with their circumstances or the policies that regulate their lives. Rather, I consider these cases of Syrians who have become involved in Turkish socio-religious life for what they might reveal about the nature of displacement and identity in the Middle East. That includes how they might encourage scholars to expand their conception of humanitarianism beyond the workings of NGOs and to

outside of refugee camps, and the UNHCR provides a stipend to help support settlement outside of the camps. See:

Alan Makovsky, "Turkey's Refugee Dilemma: Tiptoeing Toward Integration," website, Center for American Progress, 2019, available at:

https://www.americanprogress.org/issues/security/reports/2019/03/13/467183/turkeys-refugee-dilemma [last accessed 15 May 2019].

${ }^{13}$ Alan Makovsky, op.cit, 2019.

${ }^{14}$ Syrians are able to apply for temporary protection in Turkey, which, while protecting their rights to remain in Turkey, does not afford them rights laid out in international conventions for refugees. Those under temporary protection are legally prohibited from traveling to other provinces, unless granted special permission.

${ }^{15}$ Turkey is just one country in the region that is currently hosting a large population of Syrian refugees. In Lebanon, there are more than 1.5 million refugees, and in Jordan, 1.4 million. About 20 percent of refugees in Jordan live in camps, while Lebanon was wary to create camps due to its experiences with protracted Palestinian displacement. Both countries, as well as Turkey (explored further in the section below, "Fragmented Belongings") have experienced growing anti-refugee sentiment.

${ }^{16}$ Bülent Aras and Yasin Duman, "I/NGOs' Assistance to Syrian Refugees in Turkey: Opportunities and Challenges," Journal of Balkan and Near Eastern Studies, 2019, Vol. 21(4), p. 478-491.

${ }^{17}$ Tara Polzer, op.cit., 2008, p. 477. 
remain attentive to the role played by informal social actors and networks, whether they are built upon religious identity or other potential modes of affiliation that transcend that of the nation.

\section{Beyond 'Out-of-placeness:' From Refugee to Muhacir}

In recent decades, scholars within the social sciences have become increasingly sceptical of depictions of a generalised "refugee experience," reducible to narratives of out-of-placeness . ${ }^{18}$ In the early 1990s, Liisa Malkki suggested that popular discourse, academic and policy-oriented literature, and refugee management has produced a ubiquitous way of thinking about (and conflating) identity/culture and territory/nation. These assumptions are reflected through the lexicon commonly available to speak about refugees: terms like "displacement" and "uprootedness," often associated with crises, insinuating a metaphysical attachment between place and identity. Malkki's own work with Hutu refugees, both within and outside of refugee camps, showed that interpretations of exile and home, as well as notions of identity and nation, varied depending on the circumstances of one's exile. ${ }^{19}$ Since then, anthropology has seen a proliferation of studies exploring the ways through which the category of "refugee" can be a malleable one - sometimes providing the grounds upon which people stake political and historical claims, construct senses of belonging, and build solidarities. ${ }^{20}$ This has, in many ways, weakened an emphasis on the "refugee" as the paradigmatic case of "bare life" to whom Giorgio Agamben referred, and instead encourages scholars to view refugees as agentive subjects. ${ }^{21}$

As Giulia El Dardiry observes, within studies of the Middle East, scholars have often highlighted a regionalist paradigm to counter a discourse that assumes refugees to be people out of place. This approach instead focuses on local and regional affiliations (often times Arabism and Islam) that become important in cases of mass-scale migrations and displacements. In a context of neoliberal restructuring programs, scholars also point to the relevance of socioeconomic relationships. ${ }^{22}$ In the Turkish case, there remains a fairly clear division in public discourses between Syrians and Turks - especially, perhaps, given their linguistic and ethnic distinctions. Rather than reject difference, interlocutors often reproduced (and idealised) ethno-national diversity, expressing a cosmopolitan intrigue with culinary, linguistic, and other cultural practices. At the same time, they emphasised the importance of another, unifying identity: belonging to a global Muslim community, which they referred to as the umma. ${ }^{23}$

\footnotetext{
${ }^{18}$ Liisa Malkki, "National Geographic: The Rooting of Peoples and the Territorialization of National Identity Among Scholars and Refugees," Cultural Anthropology, 1992, Vol. 7(1), p. 24-44.

${ }^{19}$ Ibid., p. 34-37.

${ }^{20}$ This is a theme explored in anthropological literature pertaining to Palestinian refugees especially, given the protracted nature of their displacement. See, for instance, Julie Peteet, Landscapes of Hope and Despair: Palestine Refugee Camps, Philadelphia, University of Pennsylvania Press, 2005; Ilana Feldman, Life Lived in Relief:

Humanitarian Predicaments and Palestinian Refugee Politics, Oakland, University of California Press, 2018.

${ }^{21}$ Giorgio Agamben, "We Refugees," Symposium, 1995, Vol. 49(2), p. 116.

${ }^{22}$ Giulia El Dardiry, "'People Eat People': The Influence of Socioeconomic conditions on Experiences of Displacement in Jordan," International Journal of Middle East Studies, Cambridge, Cambridge University Press, 2017, p. 703.

${ }^{23}$ In her ethnography of migrants' conversions in Kuwait, Attiya Ahmad explores the relationship between Islamic da'wa movements, cosmopolitanism, and the umma concept. See: Attiya Ahmad, Everyday Conversions: Islam, Domestic Work, and South Asian Migrant Women in Kuwait, Durham, Duke University Press, 2017, p. 165-169.
} 
In many respects, the umma was spoken about in aspirational terms - something that Muslims must strive to realise. Participants of the religious communities (which, as a broad category, are referred to as the cemaat) often referred to Syrians as muhacir, invoking the early Muslim emigrants who fled persecution with the Prophet Muhammad from Mecca to Medina. ${ }^{24}$ Turkish interlocutors often said that Turks should act like the ansar, referring to those Muslims already living in Medina who welcomed and sheltered the Muslim emigrants. The analogy was explained to me as an attempt to recognise and negotiate ethno-national distinction, while understanding that Turks held a special responsibility to embrace their "Muslim brothers from Syria," just as the early Muslims had done with those fleeing Mecca. Within the religious communities in Fatih, usage of the term muhacir was seen as standing in contradistinction to terms like "refugees" or "guests" - terms viewed as alienating. It signalled an implicit critique of the wider Turkish public for failing to uphold their Islamic duties to support their co-religionists.

\section{Refugee as Recipient and Provider}

Much literature in migration studies has focused on the role of shared identity with regards to the proliferation of Islamic NGOs. ${ }^{25}$ These NGOs interweave a discourse of both Islamic solidarity and compassion and of neoliberal humanitarianism. While much of this literature offers generative insight into the way shared identity can be mobilised, and the multiplicity of forms humanitarianism can take, these studies tend to uphold the stark dichotomy between those "being saved" and those doing the saving - that is, humanitarian actors. They thus reproduce a generalisable image of the refugee-as-helpless-victim. Attention to social networks, on the other hand, reveals how refugees are simultaneously the recipients of support, while also participants and contributors to a community - thereby challenging the challenges of paternalism that, as many scholars note, are often associated with humanitarian endeavours.

Within the socio-religious communities, interlocutors understood themselves as both recipients and providers of support. Those who provided them with help were not impersonal bureaucratic aid workers, but instead participants in their own communities. Tarek, a Syrian man in his early 30s, who is involved with one of the communities in Fatih and works as a teacher, explained how support within the religious communities functioned:

My situation in this country is difficult. I'm having difficulty with my kimlik [an identification card] so sometimes I need help. I can ask [a respected person in the community] to help me and he will [ask the others]. They helped me to find an apartment that way, and helped me pay it when I didn't have work. Then someone else will need some help. [A respected person] will come to me, he will say 'this brother needs help' and then I can help him. ${ }^{27}$

\footnotetext{
${ }^{24}$ While deployed here as a form of camaraderie and solidarity, it is worth noting that the term muhacir, as the term musafir (guest), has been mobilised by politicians as a strategic alternative to referring to Syrians as refugees. As noted earlier, Syrians are granted temporary protection status, but are denied recognition as refugees, which would entitle them to certain rights.

${ }^{25}$ See, for instance: Mayka Kaag, "Transnational Islamic NGOs in Chad: Islamic Solidarity in the Age of Neoliberalism," Africa Today, 2008, Vol. 54(3), p. 3-18.

${ }^{26}$ Estella Carpi, "The Political and the Humanitarian in Lebanon. Social Responsiveness to Emergency Crisis from the 2006 War to the Syrian Refugee Influx," Oriente Moderno, 2014, Vol. 94(2), p. 409.

${ }^{27}$ Interview by the author with Tarek, a Syrian refugee, in Istanbul, Turkey, 13 July 2016. Interestingly, Tarek's kimlik issue resolved shortly following our initial interview, and he managed to secure semi-reliable employment.
} 
The cyclical nature of giving reflects that which Marcel Mauss described as a cycle of reciprocity, helping to bind a community together. ${ }^{28}$ Mauss suggests that individuals engage in acts of gift-giving that, although feeling to be voluntary, are circumscribed by social obligation, engaged in reciprocal cycles of giving, receiving and returning gifts. At the time of my fieldwork in Summer 2019, Tarek was renting out a room in his apartment at a low cost to a Turkish friend who had fallen on difficult financial circumstances - further reflecting the cycle of reciprocity that occurs within this context. Apartment sharing was one common way Syrians, and others, found support through the network. Several interlocutors who were struggling financially were given affordable housing through dormitories associated with religious communities.

Tarek's role as both receiver and giver of support reflects what Noga Malkin, writing in a context of formalised humanitarian endeavours, describes as "a more fluid understanding of refugees as people located in various, fluctuating, positionalities. ${ }^{, 29}$ Indeed, Syrians like Tarek who had been involved in a community for extended periods of time often served in multiple symbolic and practical capacities and had gained a level of respect that they often did not feel in other spaces. Because Syrians were often viewed as being well educated in traditional Islamic studies, including Qur'anic recitation, they were often called upon to lead the community in prayers. This was the case not only within the weekly gathering I attended, but also within the other Sufi communities I observed, where the leaders of the religious orders would occasionally step aside to allow a Syrian theology student or elder to lead.

In terms of serving in functional humanitarian roles, Syrians who had strong networks with both Turks and Syrians were often called upon as intermediaries in charitable giving. Shadi, another long-time participant in the community, said that Turkish friends would often ask him if he knew of families that needed support, especially around holiday times. ${ }^{30}$ "It has become about people you trust," Shadi said, explaining why people elected to donate their charity through his social connections, rather than through NGOs. "It's moved away from giving to [humanitarian organisations] to more private and personal giving. They [Turkish people] want to know that you know the person." He, as the majority of my Syrian interlocutors, voiced critiques of how NGOs were thought to distribute their funds. Knowing that I was studying humanitarianism, Syrians would frequently engage me with questions (and opinions) along the following lines: "Do you think that [specific NGO] is really doing anything? Maybe they rarely do projects, but there's lots of media and photographs. They exaggerate I think., ${ }^{31}$

These religious networks also provided Syrians with important social relationships that helped them feel grounded in Turkey. While Shadi appreciated the theological teachings, he spoke about the Nurcu community, and other religious involvements, primarily as fulfilling social and practical needs that helped him feel more comfortable in Turkey. He maintained a certain pride in being familiar with Turks, and believed that it would help his upward mobility. He explained:

You need some way to meet new people. In Istanbul, it's either mosques during prayer services, or the cemaats. Or you go and have coffee or something, but at a café, but practicing

\footnotetext{
${ }^{28}$ Marcel Mauss, The Gift: Forms and Functions of Exchange in Archaic Societies, Chicago, Hau Books, 2016.

${ }^{29}$ Noga Malkin, "My Brother's Keeper: The Double Experience of Refugee Aid-Workers," Journal of

Peacebuilding \& Development, 2015, Vol. 10(3), p. 47.

${ }^{30}$ Interview by author with Shadi, Syrian refugee, Istanbul, 5 August 2019.

${ }^{31}$ Informal discussion between author and Syrian refugee, Istanbul, 25 June 2019.
} 
Muslims will not go there, for people who don't want to be seen in that climate. ${ }^{32}$ Cemaat is the best substitute that there is now ... It's because of the cemaats that I know the Turkish community here more than the Syrians. I wanted to know the Turkish [people], so I know how they act and so that I could learn Turkish.

For many Syrians, the Turkish language posed a major barrier to feeling comfortable in the country. Shadi, having learned Turkish by living with Turkish-speakers and involving himself in religious communities, emphasised that he held a certain attachment to Turkey that many other Syrians he had met did not experience. In general, the Syrians involved with the Islamic communities in Fatih had achieved basic proficiency in Turkish and also spoke of a long-term future for themselves in Istanbul.

\section{Fragmented and Precarious Belongings}

Feelings of belonging were often brought into question by discrimination and discomfort Syrians faced in other contexts. In recent years, anti-refugee sentiment has grown increasingly pronounced in Turkey. While Turks initially believed that Syrians would return to their homes shortly after they began arriving to the country in 2011, their protracted presence has brought under scrutiny the AKP's ostensibly hospitable policies, as well as its support for Syrian rebels fighting Bashar al-Assad. Increasingly, opposition parties have framed the AKP's policies in Syria as entrenching Turkey in conflict with its neighbours and contributing toward an overburdening refugee crisis. In political discourse, the refugee situation has been blamed for a worsening economy and many secularists argue that Syrians are turning the country more conservative. Referring to "integration" in the public discourse is now politically untenable; politicians instead refer to "harmonisation." 33 The latter accepts Syrian presence within the country, while recognising them only as "guests" who, as a generalised collective, will eventually return home.

In the increasingly tense and polarised political climate, feelings of belonging were fragmented and spatialised. Walking through the streets days after the Istanbul governor's office announced heightened regulations on Syrians, Musaib, who settled in Istanbul in 2017, looked around vigilantly for police patrols. Without being registered legally in Istanbul, he was susceptible to detention and deportation to the province where he initially registered for his residency. ${ }^{34}$ As soon as we reached a café, where a table of Turkish friends, Syrians, and several other internationals waited, Musaib grew visibly at ease, his body relaxed. His dichotomised feelings - between fear/alienation and comfort/belonging - were reflected in Musaib's very understanding of the country and its demographics. He believed that the Turkish society was "split in two halves. One half is accepting us, and loving us, and compassionate with us, they are from the same religion... but the other half, let's say, the secular Turks are not accepting us." ${ }^{\text {, I }}$ challenged him, noting that conservative politicians have pushed for tightened restrictions on Syrians lately and that many leftists (who are secular) supported Syrian rights. He added nuance to his position, explaining that some of the religious Turks did not like Syrians either, but that they must be distinguished from those who believe that "all the people are the same, because we are Muslims." He defined these people as belonging to the religious communities.

\footnotetext{
${ }^{32}$ He later explained that he preferred social spaces that were gender segregated.

${ }^{33}$ Alan Makovsky, op.cit., 2019.

34 Sarah Dadouch and Khalil Ashawi, op.cit., 2019.

${ }^{35}$ Interview by author with Musaib, Istanbul, 28 July 2019.
} 
Musaib's experiences and interpretation here counters the notion of religious identity as a generalised and shared affiliation. Not all Turks - even those who might be labelled "religious" in Turkish discourse (a dichotomy Musaib had adopted) - were understood to be welcoming simply because they shared a Muslim identity. And yet, a shared identity held acute salience in his experience, helping to build selective spaces and networks of fraternity and support where shared modes of association - in this case, Islamic identity - were emphasised. In other words, shared religious identity provided the potential for connection, but it did not guarantee it. This serves to complicate discourses that treat integration as either-or, suggesting that one might feel at place in one space, while alienated elsewhere. It seems worth noting that, despite his anxieties in Turkey - and perhaps as much because of those anxieties - Musaib has AKP flags hanging throughout his apartment. He would like to get married in Istanbul ("maybe to a Turk") and has recently begun the lengthy process of applying for citizenship.

\section{Emergent Boundaries and Stratification}

Scholars in migration studies have widely praised the role of informal social networks in helping to integrate migrants into their new country. Yet, as Brigitte Suter argues through her study of African migrant networks in Istanbul, scholarship has often overlooked the nature of exploitation that occurs within such networks. She suggests that legal and economic difference, in addition to the different lengths of time and acquired knowledge among migrants, produced new forms of stratification that encouraged jealousy and distrust. She further highlights stratification based on pre-existing divisions, especially ethnic differences that existed among the migrant communities she studied. ${ }^{36}$

Among the social networks I studied in Fatih, emergent hierarchies were subtle. The Nurcu community actively sought to eschew formalised positions of authority, and instead intended the space to be one where "brothers come together and just read."37 There was no formal membership. Nonetheless, within a network where, as I have argued, reciprocity is essential, being able to contribute (whether materially or immaterially) served as a form of social currency. This meant that those with much to contribute - whether through contributing, for instance, knowledge, or who were well-connected - found considerable respect. Those with little to contribute - namely, the most needy and "under-educated" - were unlikely to find a place within the community. Interlocutors accepted that they could not accommodate everyone, and that they did not want people to start attending merely in hopes of finding practical support - something they said occasionally occurred, especially when refugees first began settling in Fatih. One of the long-time participants said, "We have tried to do our part for our brothers, but our part is little. We cannot help everyone." ${ }^{88}$ In this sense, this community could not, and did not intend to, replace the role of the NGO.

Further, the refugee crisis has come at a particularly critical moment in Turkish politics and history - at a time when the Turkish government, under the AKP, has sought to promote a pan-Islamic vision. Indeed, under the AKP, the Turkish government has sought to extend its political reach beyond its own nation, especially in an effort to support disenfranchised and

\footnotetext{
${ }^{36}$ Brigitte Suter, op.cit., 2012, p. 220.

${ }^{37}$ Interview by author with halaqa founder, Istanbul, 30 July 2019.

${ }^{38}$ Interview by author with Turkish organiser of the halaqa, Istanbul, 11 July 2019.
} 
struggling Muslim communities globally, through what many label a form of "soft power." ${ }^{39}$ As such, it is no surprise that Syrian refugees - given the presence of nearly 4 million in the country - are often held up in public and political discourses as the paradigmatic beneficiaries of Turkish hospitality and humanitarianism. Following the coup attempt in Turkey in July 2016, for instance, Turkish media outlets were quick to point out that many Syrian refugees were "among the strongest supporters of the Turkish government." ${ }^{, 0}$ Due to the fact that much of Turkey's conservative population is proud of the AKP's positioning as a humanitarian government, it is worth considering further how discourses of humanitarianism and cultural openness are mobilised, potentially pressuring Syrians to perform certain forms of gratitude and express contentedness with their situation in Turkey.

Syrians were generally wary to complain about their situation in the country near Turks. They proceeded into political discussions cautiously and generally emphasised their loyalties to Turkey. When I asked a Syrian interlocutor whether he and his Syrian friends complained about their situation in Turkey amongst themselves, he told me, as others, that "they do, but they wouldn't want Turks to hear." I could not help but noting that he distanced himself from those who express criticisms, using the pronoun "they". "This raises questions: What sorts of acceptable speech and expressions are accepted within these social networks? What forms of compromise and censorship are expected to make such spaces "work"?

\section{Conclusion}

Refugees living in protracted contexts of displacement frequently encounter bureaucratic, legal, economic, and political issues. While much policy-oriented literature tends to focus on these challenges, many scholars have begun to consider the relationships, new forms of identities, and the various solidarities and mutual support produced through processes of emplacement. In this paper, I have suggested that shared modes of association, and religion in particular, provide helpful modes of analysis for the investigation and understanding of inclusion and refugee support. While a focus on shared affiliation risks overstating religion's role as a unifying social force, this paper instead shows that identities such as being Muslim emerge as important and unifying identities in limited spaces - analysed here through an interest in the role of Islamic social networks - rather than broadly among a population.

These social networks offer refugees support that they otherwise are likely to receive only through humanitarian agencies, and thus, present an alternative form of support and care. Rather than reproducing divisions between aid-provider and aid-receiver, or, put differently, between saviour and victim, these social networks present cases of mutual support, where roles and responsibilities fluctuate. As presented in the case of Hisham, he contrasted the motivations of those with whom he received support "based on religious reasons" to those who did so impersonally for "humanitarian reason or because they had to." ${ }^{42}$ The former he spoke about in terms of fictive kinship - that is, as his "second family."

\footnotetext{
${ }^{39}$ Sinem Adar and Halil Ibrahim Yenigun, “A Muslim Counter-Hegemony?: Turkey’s Soft Power Strategies and Islamophobia," website, Jadaliyya, 2019, available at: https://www.jadaliyya.com/Details/38646. [last accessed 8 December 2019].

${ }^{40}$ TRT World, "Syrians in Turkey celebrate government triumph over coup attempt," online video, Youtube, 21 July 2016, available at: https://www.youtube.com/watch?v=FZhIsBSgRDo [last accessed 15 May 2019].

${ }^{41}$ Informal discussion between author and Syrian refugee, Istanbul, 15 July 2019.

${ }^{42}$ Interview by the author with Hisham, a Syrian refugee in Istanbul, Turkey, via Skype, 15 March 2019.

${ }^{43}$ Interview by the author with Hisham, a Syrian refugee in, in Istanbul, Turkey, via Skype, 15 March 2019.
} 
these cases reflect how social networks can provide forms of camaraderie and community, thereby helping refugees to feel a sense of belonging in their ostensible "host" nation.

At the same time, there exists a risk in narrowly focusing on the beneficial outcomes of social networks that are built on shared modes of identification, insofar as it ignores the role of class, ethnicity, and politics.

\section{Acknowledgements}

I am grateful to the Institute for Middle East Studies (IMES) at George Washington University, which generously supported my ethnographic research during the Summer 2019. I also thank the editors of this issue, Maissam Nimer and Risha Jagarnathsingh, and the two anonymous reviewers, who helped to develop and strengthen this article through their thoughtful and constructive feedback. Most of all, I am indebted to my interlocutors in Turkey, who graciously allowed me glimpses into their lives and welcomed me into their homes and communities.

\section{Bibliography}

Sinem Adar and Halil Ibrahim Yenigun, “A Muslim Counter-Hegemony? Turkey's Soft Power Strategies and Islamophobia," website, Jadaliyya, 2019, available at: https://www.jadaliyya.com/Details/38646 [last accessed 8 December 2019].

Giorgio Agamben, “We Refugees,” Symposium, 1995, Vol. 49(2), p.114-119.

Attiya Ahmad, Everyday Conversions: Islam, Domestic Work, and South Asian Migrant Women in Kuwait, Durham, Duke University Press, 2017.

Bülent Aras and Yasin Duman, "I/NGOs' Assistance to Syrian Refugees in Turkey: Opportunities and Challenges," Journal of Balkan and Near Eastern Studies, 2019, Vol. 21(4), p. 478-491.

Feyzi Baban, Suzan Ilcan, and Kim Rygiel, "Syrian Refugees in Turkey: Pathways to Precarity, Differential Inclusion, and Negotiated Citizenship Rights," Journal of Ethnic and Migration Studies, 2017, Vol. 43(1), p. 41-57.

Estella Carpi, "The Political and the Humanitarian in Lebanon. Social Responsiveness to Emergency Crisis from the 2006 War to the Syrian Refugee Influx," Oriente Moderno, 2014, Vol. 94 (2), p. $402-427$.

Sarah Dadouch and Khalil Ashawi, "Istanbul gives Syrians one month to return to provinces in which they are registered," website, Reuters, 22 July 2019, available at: https://www.reuters.com/article/us-turkey-syrians/istanbul-gives-syrians-one-month-to-retur n-to-provinces-in-which-they-are-registered-idUSKCN1UH1Y6 [last accessed 20 August 2019].

Giulia El Dardiry, “People Eat People': The Influence of Socioeconomic conditions on Experiences of Displacement in Jordan," International Journal of Middle East Studies, 2017, Vol. 49 (4), p. 701-719.

Ilana Feldman, Life Lived in Relief: Humanitarian Predicaments and Palestinian Refugee Politics, Oakland, University of California Press, 2018. 
Mayka Kaag, "Transnational Islamic NGOs in Chad: Islamic Solidarity in the Age of Neoliberalism," Africa Today, 2008, Vol. 54 (3), 3-18.

Alan Makovsky, "Turkey's Refugee Dilemma: Tiptoeing Toward Integration," website, Center for American Progress, 2019, available at: https://www.americanprogress.org/issues/security/reports/2019/03/13/467183/turkeys-refug ee-dilemma [last accessed 15 May 2019].

Noga Malkin, "My Brother's Keeper: The Double Experience of Refugee Aid-Workers," Journal of Peacebuilding \& Development, 2015, Vol. 10 (3), p. 46-59.

Liisa Malkki, "National Geographic: The Rooting of Peoples and the Territorialization of National Identity Among Scholars and Refugees," Cultural Anthropology, 1992, Vol. 7 (1), p. 24-44.

Liisa Malkki, "Refugees and Exile: From 'Refugee Studies' to the National Order of Things.” Annual Review of Anthropology, 1995, Vol. 24 (1), p. 495-523.

Marcel Mauss, The Gift: Forms and Functions of Exchange in Archaic Societies, Chicago, Hau Books, 2016.

Julie Peteet, Landscapes of Hope and Despair: Palestine Refugee Camps, Philadelphia, University of Pennsylvania Press, 2005.

Tara Polzer, "Invisible Integration: How Bureaucratic, Academic and Social Categories Obscure Integrated Refugees,” Journal of Refugee Studies,, 2008, Vol. 21 (4), p. 476-497.

Brigitte Suter, "Social Networks in Transit: Experiences of Nigerian Migrants in Istanbul," Journal of Immigrant \& Refugee Studies, 2012, Vol. 10 (2), p. 209.

TRT World, "Syrians in Turkey celebrate government triumph over coup attempt," online video, Youtube, 21 July 2016, available at: https://www.youtube.com/watch?v=FZhIsBSgRDo [last accessed 15 May 2019].

Ihsan Yilmaz, "Islamic Populism and Creating Desirable Citizens in Erdogan's New Turkey," Mediterranean Quarterly, Vol. 29 (4). 